\title{
Fostering Entrepreneurship: Developing a Risk-taking Culture in Singapore
}

Balbir B. Bhasin

1 bout 10 years ago the Singapore Government realized that entrepreneurial spirit was lacking in its general population. These conclusions were confirmed by an empirical survey, the Global Entrepreneurship Monitor (GEM), an annual assessment of the national level of entrepreneurial activity. The paternalistic and autboritative approach of the government contributed to the general population's averseness to participating in riskoriented ventures.

Removing impediments to entrepreneurship is a key challenge for the government and the business sector if the island republic is to maintain its national competitiveness. This article explores the various initiatives taken by the government to stimulate risk-taking and attempts to ascertain if the various measures can be used as key factors to strengthen the inberent cultural values that stimulate the entrepreneurial spirit. The observations can serve as a useful tool for academics and managers in recognizing the cultural traits that influence and belp foster entrepreneurial tendencies.

Singapore is a tiny island state with no natural resources save a hard-working small population of immigrants. It is located in Southeast Asia between the nations of Malaysia and Indonesia (see Figure 1) and has thrived as a trading and shipping center since its founding by the British East India Company's Sir Stamford Raffles 188 years ago. It covers merely 650 square kilometers including a few offshore islands. Its deepwater port served the British well in shipping raw materials from the region to Europe (Bhasin and Low 2002).

The state was granted self-government by the British in 1959, and in 1963 it joined the Federation of Malaysia only to be ousted in 1965 when it became an independent republic. Since then, the country has risen to become "one of the world's most prosperous countries with strong international trading links (its port is one of the world's busiest in terms of tonnage handled) and with per capita GDP equal to that of the leading nations of Western Europe" (CIA: World Factbook 2006) Singapore is now an international city with an extremely dense population, a largely corruption-free government, a skilled and educated workforce, and a successful free economy where regional and more than 7,000 multinational companies are major investors. Per capita income has jumped in 40 years from US\$500 to US\$25,000, a growth of 50 times multiple. However, certain sectors remain "dominat- ed by government-linked companies" (U.S. Department of State 2006).

Since its independence, Singapore has been ruled by one party, the People's Action Party (PAP), which has adopted a highly controlled form of governance. The government has been involved in regulating and engineering almost every facet of society. Many have attributed Singapore's success to this autocratic form of public policy and governance.

Singapore's "miracle" has been somewhat marred by the realization that entrepreneurial activity in the nation had been on the decline for decades. This discovery was fully authenticated by an early Global Entrepreneurship Monitor (GEM) survey in 2000, which lists Singapore very low in Total Entrepreneurial Activity by Country category (see Figure 2).

This article sketches the social and economic environment in Singapore, which may have contributed to stunting entrepreneurial activity, and outlines the efforts made by the Singapore government to foster an entrepreneurial culture through a series of programs aimed at increasing the citizens' propensity and willingness to take risks. The annual GEM survey serves as an excellent tool to confirm if the programs have been successful.This case of Singapore can serve as a starting point for managers and academics in investigating the various cultural traits that need to be stimulated to encourage entrepreneurial activity.

\section{Background: Singapore Inc.}

Since independence, the Singapore government has deliberately pursued a policy of active participation in the economy by setting up "government-linked" companies (GLCs) some of which are monopolies.

Most of these companies were established in the 1960s and 1970s to help facilitate building of infrastructure and to support economic development. In the 1980s and 1990s, this was further expanded to privatization of government departments and statutory boards (Singapore Department of Statistics 2001). The stated rationale for this strategy "was to compensate for the lack of private sector funds or expertise" (Ramirez and Tan 2003).

Investment was in key sectors such as manufacturing, finance, trading, transportation, shipbuilding, and services. The listing in Table 1 (from Ramirez and Tan 2003) is not exhaustive but is indicative of the extent of the government's involvement. 


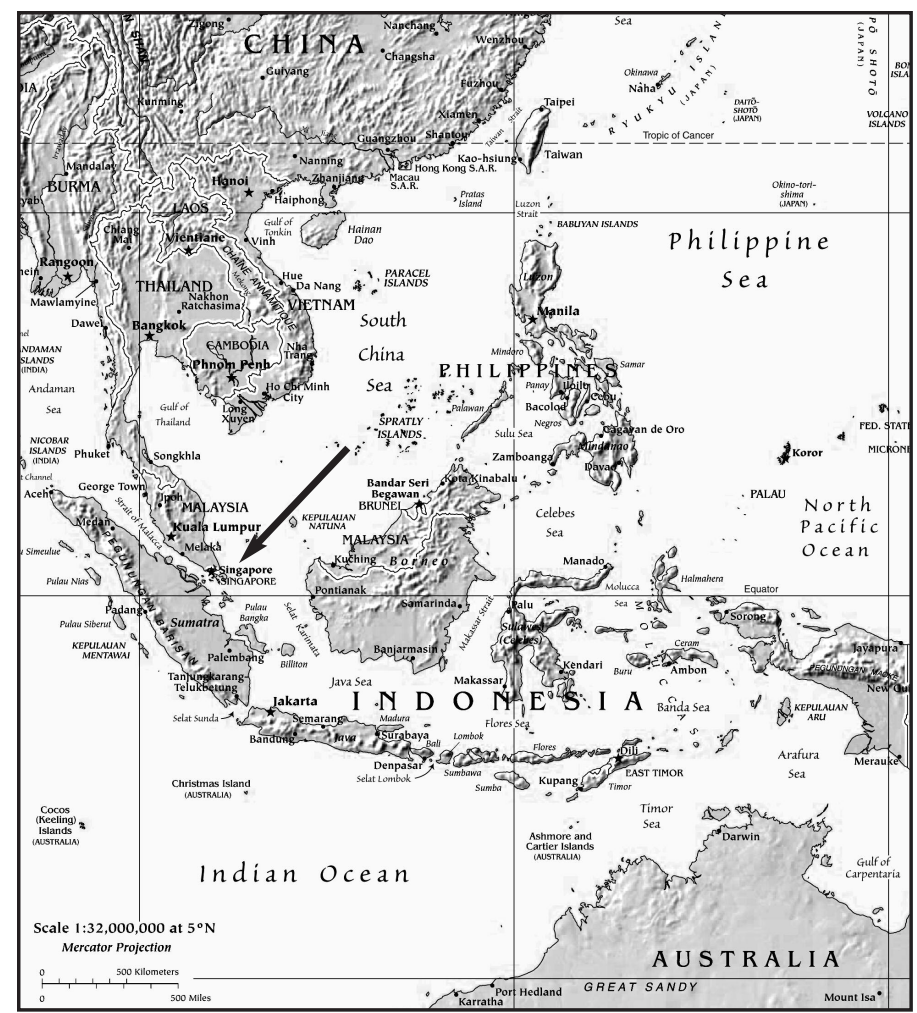

Figure 1. Singapore Is a Tiny Nation-State

\section{Located in Southeast Asia}

Source: CIA.The World Factbook, 2006.

As early as 1998, the U.S. Embassy in Singapore published a report in which it estimated that GLCs accounted for 60 percent of the domestic economy (Restall 2000). This development has been viewed as being largely unprogressive based on the argument that "GLCs tend to do better than private sector firms because their institutional relationship with the government gives them special advantages in terms of access to funds, tenders, and opportunities; consequently, they have closed large areas of the economy to the private sector and stifled entrepreneurship" (Ramirez and Tan 2004).

The conclusion that Ramirez and Tan draw in their paper for the International Monetary Fund (IMF) is that though the Singapore government claims that there is no state interference in the GLCs, that they do not receive special privileges or concealed subsidies, and are allowed to fail if they lose money, it was found that GLCs were "rewarded in financial markets with a premium of about 20 percent" (Ramirez and Tan 2004).

The 2006 Index of Economic Freedom sponsored by the Heritage Foundation and the Wall Street Journal reports that "Singapore received 22.75 percent of its total revenues from state-owned enterprises and government ownership of property" (Index of Economic Freedom 2006).

By far the biggest commercial vehicle of the Singapore government is Temasek Holdings, which was established in

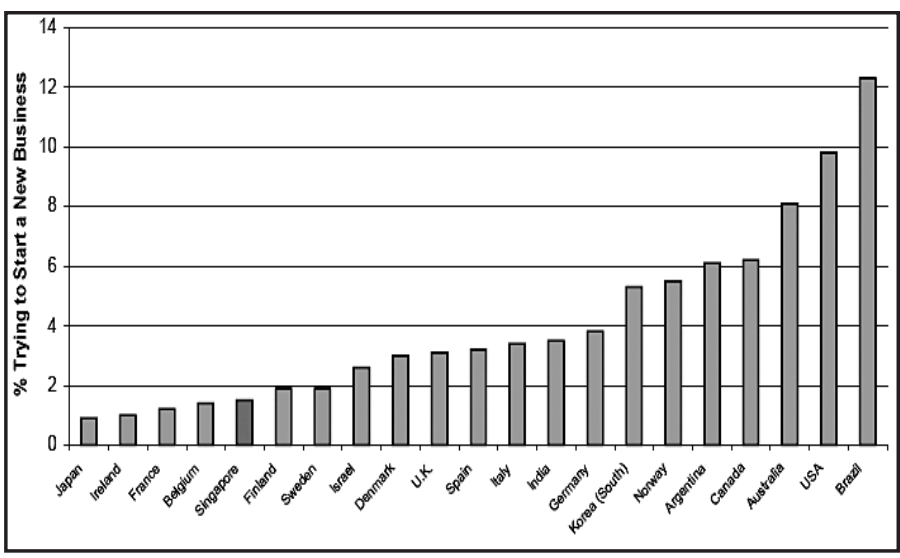

Figure 2. Total Entrepreneurial Activity by Country 2000

Source: Global Entrepreneurship Monitor 2000. Singapore Country Report, Center for Management of Innovation and Technopreneurship (CMIT), National University of Singapore (NUS), September 25, 2001.

\begin{tabular}{|ll|}
\hline \multicolumn{2}{|c|}{$\begin{array}{c}\text { Table 1. Government Investment } \\
\text { in Key Industry Sectors }\end{array}$} \\
\hline DelGro Group & TSC \\
\hline Intraco & Multiindustry \\
\hline Jurong Shipyard & Manufacturing \\
\hline Keppel Corp. & Multiindustry \\
\hline Keppel Hitachi Zosen & Manufacturing \\
\hline Keppel Marine Industries & Manufacturing \\
\hline NatSteel & Multiindustry \\
\hline Neptune Orient Lines & TSC \\
\hline SembCorp Logistics & TSC \\
\hline Singapore Airlines & TSC \\
\hline Singapore Petroleum Co. & Manufacturing \\
\hline Singapore Press Holdings & Manufacturing \\
\hline Singapore Telecoms & TSC \\
\hline SNO Corp & Manufacturing \\
\hline Times Publishing & Manufacturing \\
\hline
\end{tabular}

1. TSC $=$ Transport, storage, and communication

1974 and now has a diversified portfolio of $S \$ 129$ billion (approximately US $\$ 97.75$ billion). The firm is involved in telecommunications and media, financial services, property, transportation and logistics, energy and resources, infrastructure, engineering and technology, as well as pharmaceuticals and biosciences. The company proudly claims that total shareholders return since inception is 18 percent compounded annually (Temasek Holdings 2006). The New York Times recently reported that Temasek companies account for almost 30 percent of the economy (Arnold 2006).

The company is 100 percent owned by the Singapore Ministry of Finance. The Chief Executive of Temasek 
(appointed in 2002) is Ho Ching, who is married to Lee Hsien Loong, the newly elected prime minister of the country and son of Singapore's founding father Lee Kuan Yew. Forbes magazine cited Ho Ching as number 30 on their List of 100 Most Powerful Women in the World in 2006 (MacDonald and Schoenberger 2006).

The second investment arm of the Singapore government is the Government Investment Corporation (GIC), which invests Singapore's foreign reserves totaling more than US\$129 billion. Established in 1981, it operates as a global fund manager on behalf of the Singapore government. The board is headed by the founding father of Singapore, Lee Kuan Yew as chairman. The other members of the board are all present and past government ministers and include the current prime minister, Lee Hsien Loong, "the same safe hands who run the other government-owned companies that make up as much as 60 percent of Singapore's economy" (Ellis 2004).

On September 6, 2006, Bloomberg reported that the GIC manages the world's seventh-largest currency reserves (Whitley and Lo 2006). Its portfolio includes real estate, public markets, and special investments. The GIC does not publish the value of its assets and details of its investments are a state secret. "The fund does not have to file annual reports, justify profit-and-loss statements, or even report to Parliament" (Ellis 2004). The Singapore government claims the secrecy is to ward off "potential speculative attacks on the Singapore dollar because the foreign reserves are often used to stabilize the national currency" (Ong 2003).

There have been many calls for the Singapore government to reduce its participation in private enterprise as well as for more transparency in its current involvement. The government's position however has remained that if Singaporeans do not mind then foreigners should not question it. This is coupled with the premise that government involvement is necessary to foster growth. As recently as November 2006, the founding father of modern Singapore, Mentor Minister Lee Kuan Yew, defended Singapore's financial secrecy in spite of demands that they become more accountable.

In 2005 the IMF suggested that "Singapore should reveal the financial performance of GIC" (Burton 2006a). The Asian Wall Street Journal also noted that "if the economy is to be freed up and if entrepreneurs are encouraged to take risks in order to restore growth, full disclosure about the state's stewardship of the nation's wealth is needed" (Restall 2000). The leading Asian economic publication, Hong Kong's Far East Economic Review, reports that there is a price that Singapore has to pay for its government-led economic model. "Instead of nurturing a domestic entrepreneurial class with its own vested interests, it [Singapore] has kept the commanding heights of the economy under the control of Singapore Inc." (Restall 2006).

\section{Singapore Government's Authoritarian Approach}

The World Bank has recognized that Singapore is a leading component of the East Asian "miracle" (Richardson 1997). But Singapore's economic success has often been attributed to the authoritarian or semiauthoritarian political (and economic) control exercised by the ruling party. The country has been ruled by a single political party since independence over 41 years ago. The preferred method of governance has been to "maximize political cooperation and minimize contention" (Richardson 1997). They have allowed for little or no opposition in parliament. Opposition is considered to be disruptive and destructive. Very strict litigation results if anyone utters what the government considers is "unacceptable" criticism, and foreign journalists and their journals and newspapers are sued for libel in Singapore courts, where the judgment is invariably in the government's favor.

The government exercises virtually absolute control over most aspects of society. There is a clear and close relationship between the judiciary, government, and the media. In addition to a one-party government without opposition, the state-linked broadcaster, MediaCorp, controls all free TV channels, and Singapore Press Holdings Ltd. publishes most newspapers (Yeoh 2005).

The arrangement of GLCs and the GIC provide the Singapore government and the "ruling PAP, a network of power relations allowing it social control and political dominance... the resources for social engineering, as well as for political reward and punishment.The GLCs have tremendous influence over all Singaporeans' personal savings, housing, job opportunities and business contracts" (Rodan 2004).

Christopher Lingle's (1996) expose on Singapore's "authoritarian capitalism" contends that traditional institutions have been used to impose restrictions on individual freedoms in the pursuit of economic growth (Lingle 1996). He argues that there has been little outcry against this, as compared with "authoritarian socialism" when practiced by totalitarian regimes due to the strong economic performance exhibited in the Singapore case. The ruling party's claim of "Asian democracy" is more of a "phobocracy" - rule-by-fear, with the insinuation that Western-style democracy needs to be adjusted to suit the unique Asian milieu, which include Confucian and other traditional values. Lingle had earlier refuted these claims as attempts to "foster obedience" (Lingle 1995). This forced collectivism stifles individual innovation by free-spirited entrepreneurs.

Singapore holds that authoritarian rule is necessary to promote political stability, which in turn would lead to rapid economic development. Lingle, on the other hand, contends that Singapore's authoritarian rule has led to the "politicization of commerce, distribution of economic and commercial privi- 
leges to trusted political supporters" and this has stifled the emergence of home-grown entrepreneurs (Dorussen 1997). Singapore's authoritarianism is further exacerbated by "the merging of state and party (ruling party the PAP which) has been paramount in defining and sustaining the authoritarian regime" (Rodan 2006).

\section{Social Engineering Policy and Monopoly of Talent}

To achieve national goals of economic development, maintaining peace and harmony within the multiethnic population, and cope with restructuring needs required to compete in the global marketplace, the Singapore government set about crafting a culture based on the top-down technocratic model (Haley and Low 1998). The restructuring of society meant intervention in all aspects of social life, and this was based on the following core values as identified and continuously modified by the government (Haley and Low 1998):

1. Community over self

2. Upholding the family as the basic building block of society

3. Resolving major issues through consensus instead of contention

4. Stressing racial and religious tolerance and harmony

5. Honest government

6. Compassion for the less fortunate

Singapore's policymakers, under the patriarchal leadership of Lee Kuan Yew, decided that Confucian way reflected Asian values and would be the guiding light in structuring the society to ensure survival and success in the changing global environment. These values include the need for hierarchal structures and a compliant and docile society, an emulation of the early Chinese society where the emperor was the head of the nation (hence the Middle Kingdom-between heaven and earth) and the father, the head of the family. The assumption naturally was that these were shared beliefs of the majority population which are of Chinese origin.

The fundamental precept of Confucian thought is that a greater emphasis is placed at all times on the community over the individual. The individual must be sacrificed over the community. Lam Peng Er (2003) argues that there were four motivations for the promotion of Asian values by Singapore's top Western-educated elites:

1. Propagation of these values would be less controversial, less divisive, and more acceptable to Singaporeans of all origins.

2. Promotion of these values would allow for soft-authoritarian rule and elites would conveniently wield power by the consent of the masses.

3. The internalization of these values would inoculate Singaporeans against the selfish, decadent, and individualism of Western society.
4. Liberal democracy, while suitable to the West, may divide, destabilize, and ruin Singapore.

The desirable Confucian values were

1. Deep respect for education and a competitive education system

2. The best students become scholar-bureaucrats

3. A meritocratic government whose political leaders are also top scholars

4. Thrift and hard work

5. Filial piety

6. A patriarchal society

7. A social contract between the benevolent and virtuous rulers and grateful, respectful, and supportive subjects

Naturally, promulgation of these meant that it served the self-interest of the ruling elites in keeping them in power and denying "political space to their domestic opponents" (Lam 2003). A consequence of this was the implementation of numerous campaigns aimed at modifying social behavior: no littering, speak Mandarin, display flags on national day, first family planning and later procreate more, be courteous, plant trees, smile more, stop smoking, say no to drugs, stay healthy, etc. Strong legislation was enacted and implemented to ensure compliance to these and Singapore carried the label of being a "fine city."

Singapore's education system was originally geared to meeting the needs of MNCs labor and skills requirements. The technocratic model that requires students be "streamed" into various specialized fields begins at an early age. Educational pathways are stratified according to ability and aptitude and this has resulted in the creation of a hierarchical and even elitist society ( $\mathrm{Ng} 2005)$. The government's contention has been that streaming prevents waste by reducing the drop-out rate.

The creation and promotion of a scholar-led bureaucracy meant that the best and the brightest were recruited to enter the government. Through the education system and competitive examinations, a scholarship-awarding mechanism was created to channel top academic brains for political, military, and business leadership.This, in turn, led to the creation of an elite ruling class and the monopoly of talent to serve the needs of the government-and it kept the best from opposing the ruling party. Almost every cabinet minister and top bureaucrat in the administrative service, military and police commanders, the heads of statutory boards, and senior executives of government-linked companies have come from this system (Seah 2006a).

The government considers the technocratic approach a necessity to achieve national goals over a shorter period of time without too much sidetracking and unnecessary experimentation. Haley and Low contend that the technocratic approach has resulted in Singaporeans losing its creativity 
and entrepreneurship that the nation so essentially needs (Haley and Low 1998).

Chew and Chew's (2003) research confirms that the public sector has absorbed too much local talent, and this has created a shortage in the private sector of innovative and creative individuals capable of assuming this role. The government needs to gradually release the most capable human talent that it is presently hoarding (Chew and Chew 2003).

\section{Risk Avoidance Tendency and Lack of Creativity}

Singapore has come a long way from being a labor-abundant and capital-scarce struggling economy to a labor-scarce and capital-abundant country. It has also progressed from its early beginnings as a labor-intensive manufacturing base for international corporations to a high value-added services-based center specializing in trading, transportation, finance, and telecommunications. The country now needs to advance to the next stage of innovation and creativity to remain competitive (Chia 2005).

The then prime minister of Singapore, Goh Chok Tong, acknowledged in his National Day address in 2002 that the dearth of entrepreneurs is due to an overemphasis on rigid, structured education, and this stifles creativity and risk-taking. He noted that studies in the United States have shown that entrepreneurship is closely related with the level of cultural vibrancy. Studies have also shown that the arts can help individuals to become more creative in areas beyond the arts. They are an important source of inspiration and a powerful avenue for individual expression (Singapore Government Press Release 2002).

Numerous reasons have been cited to explain the riskaverse culture in Singapore. Low (2006) in his study of cultural obstacles in growing entrepreneurship in Singapore lists the following:

1.Young "Singaporeans remain cautious because of what they have seen, growing up in a PAP dominant landscape." The society was basically very compliant and lacked a diversity of ideas.

2. Eighty-five percent of focus groups in the study felt that the educational system had encouraged the learning of knowledge and facts and not necessarily to be creative.

3. Singaporeans are too "left-brained and textbook oriented" and were a "pampered lot" who had grown up in a "cushy environment."This made them less street-smart.

4.There was a "strong reliance on the government to do things for people." By force of habit people were led to thinking that the government would be looking after them.

5.The social culture considers failure as an embarrassment. "Kiasusim is a bane; being kiasu worsens
Singapore's entrepreneurial situation." People are concerned about the "face" or "standing in their own group." In other countries failure is more acceptable as it is considered a process of learning.

A very recent debate highlighted the fact that Singaporeans were good at academics but lacked street smarts. They fall short on individual initiative and rely too much on the government for help. Singaporeans, it was felt, functioned well only as a group, not as individuals; they were not capable of being nonconformist or of standing out above the crowd. The fault, it was claimed, lay in years of political and social conditioning by a top-down government, which was efficient but paternalistic. Everything was so structured that people did not need to fight for a living, and this blunted their ability to compete. One could keep the people's compliance by "keeping their stomach full and their mind empty" (Seah 2006b).

\section{Programs to Stimulate Entrepreneurship}

One key requirement for fostering an entrepreneurial culture is the "removal of all barriers, particularly those created by government or within its power to change, that block or discourage people's entrepreneurship" (Davis 2002).

In preparing for Singapore's entry into the 21 st century, the government included the need to develop and foster an entrepreneurial environment in its Master Plan, aptly named 'SME21' - reflecting the efforts to stimulate high-tech small and medium enterprises (SMEs) moving away from the earlier focus on MNCs and larger corporations. Earlier in 1999 it had already launched the Technopreneurship 21 (T21) program, which was designed to develop entrepreneurship involving technology and innovation. An Economic Review Committee was formed in December 2001 to develop the necessary goals and strategies.

Singapore already had a pro-business environment but no protection was accorded to small businesses and SMEs, which naturally could not compete with larger and wellestablished corporations (Tan 2003).

1. Start-ups and SMEs did not have adequate access to capital, though the financial sector was highly liberalized and developed. Banks did not specifically focus on the financial needs of smaller enterprises (Tan 2003).

2. No provisions were at hand to help entrepreneurs compete in an environment of globalization, even though Singapore had been ranked as the third most "globalized" country by A.T. Kearney/Foreign Policy Magazine Index 2001 (Tan 2003).

3 . Entrepreneurs felt that they were victims of overregulation and the high costs of fees and licenses they were required to comply with.

Consequently, a concerted effort was made by the Singapore authorities to make the changes necessary to rec- 
tify the prevailing situation and a number of programs were created.

In March 2000, a \$10 million fund, called The Enterprise Challenge (TEC), was set up to sponsor innovative proposals that encourage creativity, innovation, and enterprise through the provision and improvement of public services.

\section{Entrepreneurship Assistance}

Entrepreneurship Assistance provisions were created to encourage and support local enterprises. The following agencies were set up to promote entrepreneurial activity:

- Singapore Productivity Innovation and Growth (SPRING Singapore) is the first stop for all entrepreneurs. Its objectives are to promote a pro-business environment, to champion industry development, to enhance enterprise capabilities, and to market access and opportunities. Services provided include standards and research, patent information, current awareness, online information, and a technical library.

- Enterprise One Singapore (EnterpriseOne) helps local enterprises find the answers they need to start, sustain, and grow their businesses.

- Singapore Entrepreneurs (SGentrepreneurs) is a public site for entrepreneurs, venture capitalists, and business plan competition organizers to "blog" about their experiences in entrepreneurship and enterprise in Singapore.

- International Enterprise Singapore (IE Singapore) is responsible for taking enterprises abroad.

- Agency for Science and Technology Research (A*Star) fosters scientific research and exploitation of technology through incubators.

- Action Community for Entrepreneurship (ACE) is a change agent in building a more pro-enterprise environment through: facilitating discussion and debate on the regulatory framework; changing culture and mindset; improving access to finance; and facilitating networking and learning.

\section{Entrepreneurship Incentives}

Entrepreneurship Incentives were introduced to encourage as well as remove obstacles that were preventing entrepreneurial activity. Incentives include:

- Tax exemption for start-ups. A special tax incentive was introduced for start-ups in Singapore where they are not required to pay tax on the first $\$ \$ 100,000$ of chargeable income (excluding Singapore franked dividends) for any of the first three years of tax assessment falling within year of assessment 2005 to 2009.

- Government tax incentive schemes. Such schemes include the Double Tax Deduction (DTD) for Market Development, a tax incentive offered to Singapore com- panies to expand their overseas markets. Under this scheme, companies are allowed to deduct twice the amount of allowable expenses incurred in approved projects from their taxable income. The DTD for Overseas Investment Development Expenditure is a tax incentive to encourage exploration of overseas investment opportunities, enhance their competitiveness, and expand their operations in foreign markets.

- Government financing programs. Special schemes include Local Enterprise Finance Scheme (LEFS), fixed interest rate financing programs designed to encourage and assist local enterprises to upgrade, strengthen, and expand their operations; the Micro Loan Program (MLP), a fixed interest rate financing program under LEFS designed to help the very small local enterprises gain better access to financing;Variable Interest Loan Scheme (V-Loan), the Loan Insurance Scheme (LIS), which complements the existing LEFS scheme. It provides an additional form of financing for SMEs by allowing more flexibility for financial institutions to package attractive loan facilities to SMEs based on their risk profile and the Local Enterprise Technical Assistance Scheme (LETAS), a scheme to help local enterprises defray the cost of engaging an external expert for a limited period of time to modernize and upgrade their operations. The Overseas Enterprise Incentive (OEI) is designed to encourage and support local enterprises to penetrate new markets, explore new business opportunities, and find new avenues for resources and technology. It allows the qualifying companies to be exempted from taxation for income arising from overseas investments, such as dividends, royalties, interest income on shareholder loans, incremental income from provision of support services, and overseas project income. Finally, the Revised Overseas Investment Incentive (OII) is a tax incentive to help Singapore-based companies internationalize their operations. It is designed to encourage Singapore-based companies to expand their operations overseas by allowing them to defer taxes due from profitable operations in Singapore.

- Economic Development Board (EDB) Start-up Enterprise Development Scbeme (EDB SEEDS). This matched equity financing scheme is administered by EDB to foster entrepreneurship and innovation activities in Singapore. Start-ups can apply for SEEDS equity financing when they are in their early stages. Every dollar raised by a start-up from third-party investors will be matched by EDB up to a maximum of $\$ \$ 300,000$. Thirdparty investors must put in a minimum of $\$ \$ 75,000$ each. Both EDB and the third-party investors will take equity stakes in the company in proportion to their investments. 
- SPRING SEEDS. Nontechnology start-ups can apply for SPRING SEEDS equity financing when they are in their early stages. Every dollar raised by a start-up from thirdparty investors will be matched by SPRING Singapore up to a maximum of $\$ \$ 300,000$. Third-party investors must put in a minimum of $\$ \$ 50,000$ cumulative. Both SPRING Singapore and the third-party investors will take equity stakes in the company in proportion to their investments.

- Enterprise Investment Incentive (EII) Scheme. This tax-incentive scheme allows investors in innovative start-ups to deduct their investment loss amount against their taxable income. With EII status, a start-up can issue certificates to its investors for investment of up to $\$ \$ 3$ million. Investors with these certificates can deduct any investment loss from their taxable income.

- Growth Financing Program. This program is designed to support early stage, Singapore-based companies that have the potential to become global competitive enterprises. Companies that have successfully completed their product development with early customer traction can apply for equity financing for earnest overseas market expansion activities through the Growth Financing Program. Potentially, every $\$ \$ 2$ raised by the growth company from third-party investors will be matched by $\mathrm{S} \$ 1$ from $\mathrm{EDB}$, subject to a maximum of s\$1,000,000 under both the SEEDS and Growth Financing Programs. Minimum investment from thirdparty investors is $\$ \$ 500,000$. Both EDB and the thirdparty investors will take equity stakes in the company in proportion to their investments.

- ACE's Action Crucible for Financing Scheme. This scheme is one of four action crucibles formed under the Action Community for Entrepreneurship (ACE) to improve SMEs' access to financing, as part of the impetus to foster greater entrepreneurship in Singapore.

- Home Office Scheme. In this scheme, which is designed to facilitate entrepreneurship, Housing and Development Board (HDB) subsidized apartments can be used as a home office and for business registration.

- Local Enterprise Technical Assistance Scheme. This scheme will subsidize (up to 50\%) the cost of hiring a consultant to implement quality management and IT systems (e.g., upgrading computer systems or ISO projects).

- Patent Application Fund Plus. Designed to encourage investors to patent innovations and commercialize their inventions, this scheme offers help on covering some of the costs of filing patent applications, such as professional and official fees and other related charges of patent filing.

\section{Entrepreneurship Education}

- National University of Singapore (NUS) Entrepreneurial Center. This center offers a wide range of entrepreneurship courses for all undergraduate and graduate students, to raise awareness and interest in entrepreneurship among the NUS community and to conduct cuttingedge research on key issues of entrepreneurship.

- Entrepreneurs Resource Center (ERC). The ERC provides specialized training programs that are tailor-made for the business environment, as well as specially crafted curriculum with a unique approach of integrating reallife experience and case studies to refine business and professional skills. ERC emphasizes a holistic approach to encourage entrepreneurship

\section{Amending Legislation that Stigmatizes Failure}

The arcane bankruptcy law was amended to encourage entrepreneurship. Previously a bankrupt person could be discharged only after paying most of his or her debt.The amendments in 1995 and 1999 now allow the Official Assignee to grant a discharge for debts below $\$ \$ 500,000$ after three years in bankruptcy.The amount of debt for which bankruptcy proceedings may be instituted was raised to $\$ \$ 10,000$. The period during which a debtor can attempt to arrange a settlement was raised to 45 days (Tan 2003).

\section{Creativity and Innovation}

Creativity and innovation are officially encouraged and fostered with the introduction of several initiatives, including the establishment of Creative Community Singapore, an initiative to provide opportunities for Singaporeans to express their creativity and deploy their creative energy for community benefit, to evolve a creative and connected community where arts, culture, business, and technology converge to empower and engage individuals.

\section{Education Reform: Changing the Mindset}

Singapore's school system has been based on the concept of meritocracy based on progress for those with ability and talent. For many, their future is determined at the age of 12 through the streaming exams. The result has been an emphasis on rote learning instead of critical thinking and the creation of a skilled, but compliant workforce. No opportunity is given to slow learners or late bloomers. Parents have also complained that the system stigmatizes some children early on as failures (Burton 2006b).

Realizing that the education system needs to be adjusted to allow for creative thinking as well as developing individual abilities, the government is now trying to loosen up and encourage creative thinking. A number of government measures are under consideration for implementation. A review 
committee recently concluded the need to change the mindset though the education system and recommended that "Singapore's education formula needs to move from uniformity to diversity, from rigidity to flexibility, from conformity to resilience, and from molding to empowering" (FitzPatrick 2003).

Changes need to be made to the exam and skill-oriented system from focus on raw grades to fostering creativity and innovativeness. The focus at all levels will now be to nurture flexible mindsets, shift emphasis from teacher to learner, and "transform from being just a productive society into a creative and risk-taking society" (FitzPatrick 2003).

\section{Loosening Reigns to Foster Entrepreneurship}

The first step to dealing with any issue is recognizing the problem. Singapore authorities have conceded that a dire need exists for building a class of entrepreneurs who will take the national economy to greater heights. This must mainly be done by the private sector but the government must ensure that a climate for innovation, creativity, and risk-taking exists. Many government leaders have stated that they are willing to allow for dissent and reduction of controls. Although much publicity was generated in the last 10 years that this was going to be done, this has been mainly lip service. Just recently in 2006 strong action was taken to prevent protests at the World Bank and IMF meetings held in Singapore and now new legislation is being planned to stop Internet blogs from criticizing the government.

\section{Net Result: Decrease and Increase in Entrepreneurial Activity}

The first GEM study (circa 2000) on the level of entrepreneurial activities in Singapore found it to be relatively low in comparison with the other countries. Singapore was ranked 17 out of 21 on the total entrepreneurial activity (TEA) index. The biggest impediment factors reported was the value orientation of the people-preferring to work for larger, established organization and fear of failure (GEM 2000).

The level of TEA improved substantially from 27 out of 29 nations in 2001 to 21 out of 37 nations in 2002, although the total entrepreneurial propensity for 2002 declined in comparison to 2001. The two most important dimensions that required improvement were social and cultural norms and barriers to entry (GEM 2002). There was a further decline in 2003 and the main reason cited was the occurrence of the SARS crisis, a viral infection that plagued most Southeast Asian nations. "Cultural values" continued to receive low ratings (GEM 2003).

The year 2004 saw the first major rise in TEA to 5.7 percent from 5.0 percent in 2003. Singapore's relative ranking among the Organization of Economic Cooperation and
Development and East Asian countries improved slightly from 14 of 21 in 2003 to 11 of 21 in 2004.

Improvements were reported in the following dimensions:

1. Effectiveness of R\&D transfer

2. Availability of capital

3. Government policy support

4. Access to physical infrastructure

5. Effectiveness of university, management education, and training

Lower ratings for Singapore were in the following areas:

1. Effectiveness of primary and secondary education and training

2. Rapidity of change in markets

3. Market accessibility

4. Social and cultural barriers

Singapore saw the highest increase in TEA in 2005 (up from $5.7 \%$ to $7.2 \%$ ) since it began participating in GEM in 2000. This increase outpaced that of the developed OECD countries. The country was ranked 8 of 20 . Improvements were reported in the following dimensions:

1. Regulation and taxation system

2. Government policy support

3. Market accessibility

Areas in which Singapore was rated lower were:

1. Effectiveness of university education and training

2. Business service effectiveness

3. Availability of capital

4. Social and cultural barriers

Table 2 summarizes the changes in TEA and country ranking for the years 2000 to 2005.

The constant lower ratings have been on social and cultural barriers. The GEM 2001 Executive Report clarifies that this is the most pressing issue and describes it as the "public's general attitude towards entrepreneurship." In nearly every country, this was found to be the greatest inhibitor to, or enhancement of, entrepreneurship. GEM specialists agreed

Table 2. TEA for Singapore 2000-2005

\begin{tabular}{|l|l|l|}
\hline Year & TEA (\%) & Country Ranking \\
\hline 2000 & 2.1 & 17 of 21 \\
\hline 2001 & 6.6 & 27 of 29 \\
\hline 2002 & 5.9 & 21 of 27 \\
\hline 2003 & 5.0 & 14 of 21 \\
\hline 2004 & 5.7 & 11 of 20 \\
\hline 2005 & 7.2 & 8 of 20 \\
\hline
\end{tabular}

Source: GEM 2000, 2002, 2003, 2004, 2005. 
Table 3. Democracy Index 2007: The Economist Intelligence Unit

\begin{tabular}{|l|l|l|l|l|l|}
\hline Full Democracies & Rank & Flawed Democracies & Rank & Hybrids & Rank \\
\hline Sweden & 1 & South Korea & 31 & Albania & 83 \\
\hline Iceland & 2 & Taiwan & 32 & Singapore & $\mathbf{8 4}$ \\
\hline Netherlands & 3 & India & 35 & Madagascar & 85 \\
\hline Norway & 4 & Philippines & 63 & Lebanon & 85 \\
\hline Denmark & 5 & Indonesia & 65 & & \\
\hline Finland & 6 & Bangladesh & 75 & & \\
\hline Luxembourg & 7 & Hong Kong & 78 & & \\
\hline Australia & 8 & Malaysia & 81 & & \\
\hline Canada & 9 & & & & \\
\hline Switzerland & 10 & & & & \\
\hline
\end{tabular}

Source: http://singaporeelection.blogspot.com/2006/11/shameful-democracy-for-singapore.html.

that a society's negative posture with respect to creativity, innovation, and change significantly reduces the number of people engaged in starting new firms. The experts were also clear that a culture that rewards risk-taking is more inclined to support higher levels of entrepreneurial activity. Willingness to accept failure also tends to be associated with higher levels of risk-taking (GEM 2001).

\section{Conclusion: More Can and Needs to be Done}

The Economist (UK) ranks Singapore 84 among 167 countries in its 2007 Democracy Index. The index was developed by The Economic Intelligence Unit (EIU). Singapore is listed as a hybrid regime (mixture of authoritarian and democratic elements) and ranks well below Finland (6), Malaysia (81), Hong Kong (75), Taiwan (32), and Indonesia (65). The index looks at 60 indicators across the five categories: electoral process and pluralism, civil liberties, the functioning of government, political participation, and political culture (Economist 2006).

In its Press Freedom Index, Reporters Without Borders ranked Singapore 146 out of 167 countries surveyed for press freedom. At the top of the list were Finland, Iceland, Ireland, and the Netherlands while North Korea was last (Press Freedom Index 2006).

It is clear from both reports that Singapore needs to do much more in loosening its reigns of the population for them to feel comfortable in a free society and become more willing to take risks. The basic fact remains that in the current Singapore business environment, the societal culture is antithetical to the entrepreneurial spirit.

A business venture is a contradictory dynamics between risk and risk awareness. A business that is purely based on risk is an irrational undertaking. The ideal business venture is one that reflects the following:

\section{Risk > Risk Awareness}

Unfortunately in Singapore, the formula is reversed:

Risk Awareness > Risk

In the United States, it has been concluded that entrepreneurs do not consider themselves to be risk-takers. "They have weighed the pros and cons and convinced themselves that their so called risky idea isn't that risky after all" (Boyett 2001). The paradox of risk is that you cannot afford not to take it. "Nobody knows more about risk and how to live with it than entrepreneurs" (Wacker 2001).

Risk averseness can be described as the unwillingness to take risk due to the inherent fear of failure. It is an attitude that promotes "playing it safe" in line with the oft-repeated adage "you can't do wrong if you do nothing!" which naturally results in absolute minimization of any risk factors. In the Oriental world, fear of failure is further reinforced by the need to save "face." 
Kreiser, Marino, and Weaver's 2002 study empirically proves that national culture has a direct and identifiable impact on the level of entrepreneurial behavior. The study utilized data from 1,070 firms in six countries to assess the impact of national culture on entrepreneurial orientation. The impact of culture was examined on two key dimensions: risk-taking and proactive behavior. Their argument suggests that by changing the "predominant cultural values in a given society, policy makers can act as a catalyst to entrepreneurial development" (Kreiser, Marino, and Weaver 2002).

Singapore's success and weakness lies in this setup. Entrepreneurship is a result of two interdependent factors:

1. A vibrant culture that is willing to take risk and values the freedom of risk, and

2.A social system that channels and rewards the risk-takers so that society as a whole can benefit from the talent in due time.

A society that has traditionally focused attention on "control" rather than "free spirit" when confronted with the "new economy" has extreme difficulty in reducing the controls and increasing the free spirit. This is the key factor that destroys entrepreneurial spirit in any economy, and is the dilemma between "security" and "risk." The choice for Singapore is obvious. A truly entrepreneurial culture is built around accepting failure as commonplace and risks continue to be taken because there is little to lose. This may not be the case for Singapore where most citizens are simply too well off and cozy.

Financial incentives, tax breaks, and infrastructure improvements do certainly lead to increase in entrepreneurial activity, as is the case in Singapore. But a desire for true innovation, creativity, experimentation, and multiple opportunities in education cannot be realized until the state allows civil society to flourish and avoids politicizing dissent (Tan and Gopinathan 2000). As long as the Singapore government is unwilling to allow natural forces to prevail, allow open expression and free flow of ideas, and encourage out-of-thebox thinking that will unveil the creative and innovative energies that currently are dormant, only limited progress in fostering an entrepreneurial culture can be expected.

\section{Postscript}

The GEM Survey for 2006 was released after completion of this article but before publication date. Results released on February 9, 2007 show that Total Entrepreneurial Activity (TEA) went down from 7.2 percent in 2005 to 4.9 percent in 2006, placing Singapore 16 among the 22 members of the OECD that were surveyed (Strait Times 2007).

\section{References}

Arnold, Wayne. 2006. Telecom deal by Singapore riled Thais. New York Times (October 3).

Bhasin, B., and Low, Patrick. 2002. The fight for global talent-New directions, new competitors. Career Development International 7, 2: 109-114.

Boyett, Joseph, and Jimmie Boyett. 2001. The guru guide to entrepreneurship. New York: John Wiley and Sons. Burton, John. 2006a. Singapore defends financial secrecy. Financial Times, London (November 5).

Burton, John. 2006b. Stellar results mask a lack of flexibility. Financial Times, London (October 18).

Chew, Soon Beng, and Rosalind Chew. 2003. Promoting innovation in Singapore: Changing the mindset. International Journal of Entrepreneurship and Innovation Management 3, 3: 249-266.

Chia Siow Yue. 2005. The Singapore model of industrial policy: Past evolution and current thinking. Singapore Institute of International Affairs. Paper presented at the Second LAEBA Annual Conference, Buenos Aires, November 29.

CIA:The World Factbook: Singapore. 2006.Accessed September 19, 2006. https://www.cia.gov/cia/publications/ factbook/geos/sn.html.

Davis, Susan. 2002. Social entrepreneurship:Towards an entrepreneurial culture for social and economic development. Paper presented at the Youth Employment Summit,Alexandria, Egypt, September 7-11.

Dorussen, Han. 1997. Review of Singapore's authoritarian capitalism: Asian values, free market illusions, and political dependency. Public Choice.

The Economist. 2006. The Economist intelligence unit's index of democracy 2007.

Ellis, Eric. 2004. Singapore's GIC secrets: Inching toward transparency. Fortune 14.

FitzPatrick, Paul. 2003. Reinventing Singapore: Changing a country's mindset by changing its education system. International Higher Education (Spring).

GEM. 2000. Singapore Country Report 2000. Center for Management of Innovation and Technopreneurship, National University of Singapore (September 25, 2001). 
GEM. 2001. Executive Report. http://www.gemconsortium.org/download.asp?fid=160.

GEM. 2002. Singapore Report. National University of Singapore Entrepreneurship Center (April 2003).

GEM. 2003. Singapore Report. National University of Singapore Entrepreneurship Center (April 2004).

GEM. 2004. Singapore Report. National University of Singapore Entrepreneurship Center (February 2005).

GEM. 2005. Singapore Report. National University of Singapore Entrepreneurship Center (February 2006).

Haley, Usha, and Linda Low. Crafted-culture: governmental sculpting of modern Singapore and effects on business environments. Journal of Organizational Change 11, 6:530-553.

Index of Economic Freedom. 2006. http://www.heritage.org/research/features/index/country.cfm?id=Singapore.

Kreiser, P. M., L. D. Marino, and K. M. Weaver. 2002. Correlates of entrepreneurship: The impact of national culture on risktaking and pro-activeness in SMEs. Tuscaloosa,AL: University of Alabama, Department of marketing and Management.

Lam, Peng Er. 2003. The politics of Asian values in Singapore. East Asian Institute. http://www.aprc.jp/kokusai/2003/37.pdf. Lingle, Christopher. 1996. Singapore’s Authoritarian Capitalism. Fairfax, VA: Locke Institute.

Low, Kim Cheng Patrick. 2006. Cultural obstacles in growing entrepreneurship: a study in Singapore. Journal of Management Development 25, 2.

MacDonald, Elizabeth, and Chana R. Schoenberger. 2006. The world's most powerful women. Forbes magazine (August 31).

Ng, Weijie. 2005. Singapore educational elitism. Education and Development in Asia (August).

Ong, Lynette. 2003. Investment Singapore style. Asia Times (March 15).

Press Freedom Index. 2006. Worldwide Press Freedom Index. Reporters Witbout Borders. www.rsf.org.

Ramirez C., and H. L. Tan. 2003. Singapore Inc. versus the private sector:Are government-linked companies different? IMF Staff Paper 51, 3 .

Restall, Hugo. 2000. More transparency please. Asian Wall Street Journal.

Restall, Hugo. 2006. Financial center pipedreams. Far East Economic Review.

Richardson, Michael.1997. Despite prosperity, the governing party fears the 'knife edge': In Singapore, still a sense of fragility. International Herald Tribune (January 4).

Rodan, Garry. 2004. The coming challenge to Singapore Inc.” Far East Economic Review (December).

Rodan, Garry. 2006. Singapore 'exceptionalism'? Authoritarian rule and state transformation. Asia Research Center, Murdoch University, Working paper No. 131.

Seah, Chiang Nee. 2006a. Scholars on the wane. The Sunday Star (October 8).

Seah, Chiang Nee. 2006b. Singaporeans good at academics. The Star Malaysia (April 23).

Singapore Department of Statistics. 2001. Contribution of government linked companies to gross domestic product.

Singapore Government Press Release. 2002. National Day Rally Address by Prime Minister Goh Chok Tong at the University Cultural Center. Media Division, Ministry of Information and the Arts, Singapore (August 16).

http://www.gov.sg/nd/ND02.htm

Straits Times. 2007. Fewer Singaporeans willing to strike out on their own: Survey of the global entrepreneurship monitor 2006 (February 10).

Tan, Jason, and S. Gopinathan. 2000, "Education Reform in Singapore:Towards Greater Creativity and Innovation? NIRA Review, Summer 2000.

Tan, Wee-Liang. 2003. Entrepreneurship challenges ahead for Singapore. U.S. -Entrepreneurship in Asia: Playbook for Prosperity. Maureen and Mike Mansfield Foundation, University of Montana. http://www.mansfieldfdn.org/programs/ entrepreneurship.htm.

Temasek Holdings. 2006 .Website accessed October 4, 2006. http://www.temasekholdings.com.sg/about_temasek/ corporate_profile.htm.

U.S. Department of State. 2006. Background note: Singapore. Bureau of East Asian and Pacific Affairs. Accessed October 2006. http://www.state.gov/r/pa/ei/bgn/2798.htm 
Wacker,Watts. 2001. Risk is all.Entrepreneur Magazine (April). www.findarticles.com/cf_0/m0DTI/4_29/73121403/html. Whitley, Angus, and Bernard Lo. 2006. Singapore to lift emerging-market weighting. Boomberg (September 6).

Yeoh, En-Lai. 2005. Turning 40, Singapore leaders ease up on social engineering without ceding political control. Associated Press (August 2).

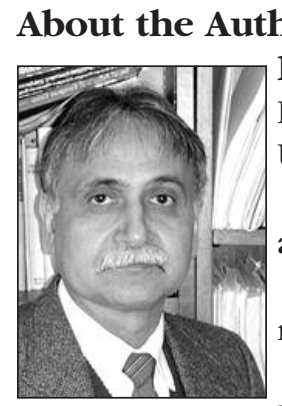

\section{NEjE-}

BALBIR B. BHAsin (bhasinb@sacredheart.edu) is an associate professor of international business at the John F. Welch College of Business, Sacred Heart University. He taught previously at Ashland University, Ohio; University of Tampa and Eckerd College, Florida; and South Texas College in McAllen.

Prior to teaching, Dr. Bhasin was simultaneously president of a private investment bank based in Hong Kong and New York, and the CEO of an international business information company based in the Far East.

He is a member of the Advisory Board of the Human Resource Institute, University of Tampa, and a researcher with the Center for Comparative Water Policies and Laws at the University of South Australia.

Dr. Bhasin is multilingual and multicultured. His education encompasses five systems: American, Asian, British, Canadian, and Australian. He has lived and worked in 12 countries.

He holds two bachelor's degrees (in the humanities and business administration) from Lakehead University, Ontario, Canada; a Master of International Management degree (with distinctions) from the Thunderbird School of Global Management, Glendale, Arizona; and a Doctor of Philosophy degree in management and international business from the University of South Australia, Adelaide, Australia. 